\title{
KEEFEKTIFAN STRATEGI TANGGAPAN DAN KOMENTAR TERHADAP BACAAN DALAM PEMBELAJARAN MENULIS
}

\author{
Restiana Wati dan Darmiyati Zuchdi \\ Program Pascasarjana Universitas Negeri Yogyakarta, Indonesia \\ email: restianawati20@gmail.com
}

\begin{abstract}
Abstrak
Penelitian ini bertujuan untuk menguji keefektifan strategi pembuatan tanggapan dan strategi komentar terhadap bacaan dalam pembelajaran menulis teks eksposisi tingkat Sekolah Menengah Pertama. Penelitian ini juga bertujuan untuk menguji kefektifan strategi pembuatan tanggapan terhadap teks, strategi komentar terhadap bacaan, dan strategi konvensional dalam pembelajaran menulis teks eksposisi. Sampel penelitian ini adalah 92 siswa yang dipilih melalui teknik cluster random sampling. Teknik pengumpulan data menggunakan tes tulis. Teknik analisis data yang digunakan adalah analisis varians satu jalan dan dilanjutkan dengan uji Scheffe. Hasil penelitian menunjukkan bahwa pertama, terdapat perbedaan yang signifikan antara strategi pembuatan tanggapan terhadap teks dan strategi konvensional. Kedua, pada penelitian ini adalah terdapat perbedaan antara strategi komentar terhadap bacaan dan strategi konvensional. Ketiga, tidak terdapat perbedaan antara strategi pembuatan tanggapan terhadap teks dan strategi komentar terhadap bacaan, namun hasil rata-rata kelompok eksperimen 1 lebih besar dibandingkan kelompok eksperimen 2. Dengan demikian, urutan keefektifan ketiga strategi tersebut adalah strategi pembuatan tanggapan terhadap teks, strategi komentar terhadap bacaan, dan strategi konvensional.
\end{abstract}

Kata kunci: strategi tanggapan terhadap teks, strategi komentar terhadap bacaan, menulis, teks eksposisi

\section{THE EFFECTIVENESS OF RESPONSE STRATEGY ON TEXT AND COMMENTS ON READING IN LEARNING WRITING}

\begin{abstract}
This study aimed to examine the effectiveness of the strategy of making responses and strategies for commenting on the reading in learning to write exposition text for Junior Hight School level. This study was also to determine the effectiveness of strategies for making responses to texts, strategies for commenting on reading, and conventional strategies in learning to write exposition texts. The sample of this study was 92 students who were selected through cluster random sampling technique. The data collection technique used a written test. The data analysis technique used was one-way analysis of variance and continued with the Scheffe test. The results showed that first, there was a significant difference between the strategy for making responses to the text and the conventional strategy. Second, result in this study is that there is a difference between the commentary strategy on reading and the conventional strategy. Third, there is no significant difference between the strategy for making responses to text and the strategy for commenting on reading, but the average result of the experimental group 1 is greater than that of the experimental group 2. Thus, the order of the effectiveness of the three strategies is the strategy of making responses to text, the strategy of commenting on readings, and conventional strategies.

Keywords: text response strategy, reading comment strategy, writing, exposition text
\end{abstract}




\section{PENDAHULUAN}

Pembelajaran bahasa tidak lepas dari empat keterampilan berbahasa, yaitu membaca, menyimak, berbicara, dan menulis. Salah satu keterampilan berbahasa aktif produktif, yaitu keterampilan menulis. Basuki dkk. (2017) menyatakan bahwa tujuan utama pembelajaran bahasa, yaitu mempersiapkan peserta didik nantinya dapat berinteraksi dengan bahasa yang bermakna. Sikap positif yang dapat ditunjukkan terhadap pembelajaran bahasa, yaitu dengan memahami secara penuh pengetahuan yang dimiliki. Keterampilan yang bersifat aktif produktif merupakan kemampuan yang menghasilkan bahasa baik secara lisan maupun tertulis. Abidin (2012, p. 182) menyatakan keterampilan menulis merupakan kemampuan untuk mengungkapkan diri melalui kata-kata dan kalimat yang disampaikan secara tertulis. Kegiatan menulis merupakan aktivitas pengekspresian ide, gagasan, pikiran, atau perasaan ke dalam lambanglambang kebahasaan. Kegiatan menulis dilibatkan berbagai aspek kebahasaan yang meliputi: penggunaan tanda baca dan ejaan, pengunaan diksi, penataan kalimat, pengembangan paragraf, pengolahan gagasan dan pengembangan model karangan.

Makna utama keterampilan menulis adalah menyusun kalimat dengan tata bahasa yang benar. Tulisan yang benar adalah tulisan yang memiliki keterkaitan antar unsur dalam struktur sintaksis atau struktur wacana (Javed et al., 2013). Menulis merupakan salah satu keterampilan berbahasa yang penting dan kompleks. Peran menulis dalam pembelajaran bahasa penting. Keterampilan menulis tidak dapat berdiri sendiri karena selalu berkaitan dengan keterampilan bahasa lainnya, yaitu membaca, menyimak, dan berbicara. Keterampilan menulis seringkali dianggap sebagai keterampilan yang sangat sulit karena berhubungan dengan ejaan dan tata tulis yang baik dan benar sesuai dengan ejaan bahasa Indonesia. Tata tulis dan ejaaan menjadi hal pokok dan penting dalam keterampilan menulis. Ketika salah menempatkan ejaan dan tata tulis dapat menimbulkan makna ambigu, yaitu makna yang susah untuk dimengerti dan dipahami.

Menulis merupakan keterampilan berbahasa yang kompleks, mulai dari pemilihan kata, penggunaan bahasa, dan ejaan. Semua komponen menulis harus selalu diperhatikan, namun tidak banyak siswa yang memerhatikan hal tersebut. Banyak siswa yang hanya sekadar menulis atau bahkan menulis dengan meniru atau menyalin tulisan orang lain. Hal tersebut tidak benar. Plagiat atau mengambil karya orang lain tanpa meminta izin merupakan hal yang tidak benar. Siswa harus ditanamkan kejujuran sejak dini, terutama dalam pembelajaran keterampilan menulis. Hal tersebut sesuai dengan pendapat Zuchdi (2011, pp. 226-227) yang menyatakan pembelajaran menulis dimulai dari sekolah dasar dan sejak itulah harus ditanamkan kejujuran dalam menghasilkan sebuah karya tulis. Pendidik harus membimbing keterampilan menulis melalui proses panjang, tidak hanya mementingkan hasil berupa tulisan yang sudah jadi.

Keterampilan menulis merupakan salah satu keterampilan yang penting. Melalui keterampilan menulis, peserta didik dapat mengembangkan berbagai ide dan gagasan yang dimilikinya melalui sebuah tulisan. Peserta didik dapat meningkatkan keterampilan menulis dengan terus berlatih menulis. Keterampilan menulis tidak hanya sekedar menulis, tetapi peserta didik dapat mengembangkan gagasan tersebut menjadi kalimat demi kalimat yang baik dan benar. Menulis adalah proses aktivitas kognitif pribadi, pengorganisasian yang menghasilkan tulisan dengan mem- 
pertimbangkan tata bahasa dan ejaan (Balta, 2018).

Kegiatan menulis berhubungan dengan situasi pembelajaran, yaitu berkaitan dengan ide-ide topik utama dalam sebuah bacaan yang diberikan oleh guru. Siswa mendapatkan informasi dan pemahaman terhadap materi yang disampaikan oleh guru (Durfee, 2012). Keterampilan menulis berkaitan dengan keterampilan membaca. Kebiasaan membaca membuat pengetahuan dan wawasan semakin banyak dan mengetahui hal-hal yang tidak kita pahami. Selain itu, dengan membaca siswa tidak akan pernah miskin kosakata. Menulis merupakan proses menuangkan ide, gagasan, dan pengetahuan dalam sebuah tulisan. Siswa lebih mudah untuk menuangkan berbagai ide dan pikiran dalam bentuk tulisan tentu harus memiliki banyak kosakata. Hal tersebut dapat ditingkatkan dengan memperbanyak membaca dan menulis. Semakin banyak bacaan yang dibaca tentu akan menambah jumlah kosakata yang dimiliki. Sikap terampil dalam mengutarakan gagasan sangat dibutuhkan dalam proses menulis agar tercipta sebuah karya tulis yang baik.

Keterampilan menulis sebagai keterampilan integratifartinya keterampilan menulis menjadi kesatuan yang utuh dengan keterampilan berbahasa yang lainnya, seperti keterampilan membaca, mendengar dan berbicara. Keterampilan-keterampilan berbahasa tersebut terintegrasi dalam keterampilan menulis. Proses penulisan perlu adanya proses membaca. Selain membaca, keterampilan mendengar atau menyimak juga berpengaruh dengan keterampilan menulis. Sesuatu yang telah diperoleh dari hasil membaca dan menyimak dapat digunakan untuk keterampilan menulis. Informasi yang diperoleh akan meningkatkan kualitas tulisan yang dihasilkan. Tulisan yang dihasilkan kemudian diungkapkan melalui keterampilan berbicara. Keterampilan berbahasa tersebut saling berintegrasi dan berpadu menjadi kesatuan yang utuh (Mochtar, 2017).

Kurikulum 2013 menggunakan pendekatan proses genre. Beberapa materi yang diajarkan berupa teks. Langkah dalam pembelajaran berbasis genre, yaitu mengenal teks, memahami teks, menganalisis teks, merefleksi, mengembangkan ide atau bahan, menyusun kerangka teks, menulis draf, merevisi, evaluasi, dan melakukan tindak lanjut terhadap teks (Syamsi, 2012)

Salah satu keterampilan menulis yang diajarkan, yaitu menulis teks eksposisi. Teks eksposisi merupakan teks yang berisi mengenai pendapat atau argumen terhadap suatu masalah yang dibahas. Pembelajaran menulis teks eksposisi dapat membuat Siswa mudah berargumenatsi melalui sebuah tulisan. Teks eksposisi merupakan teks yang di dalamnya berisi uraian atau penjelasan mengenai suatu hal. Ciri teks eksposisi adalah adanya argumen atau pendapat dari penulis yang kemudian diperkuat dengan fakta atau data-data yang mendukung. Teks eksposisi dibentuk oleh dua unsur utama, yaitu gagasan dan fakta. Gagasan tersebut berupa ide ataupun pendapat. Isinya berupa pernyataan berupa komentar, penilaian, saran, dorongan, dan bujukan. Fakta adalah sesuatu yang benarbenar ada atau terjadi. Fakta dalam teks eksposisi berfungsi untuk memperkuat gagasan (Kosasih, 2017, p. 62).

Mijianti dan Puspitosari (2019) dalam penelitiannya menjelaskan bahwa beberapa siswa yang kesulitan menyusun teks eksposisi disebabkan karena kurang aktif dalam mengikuti proses pembelajaran. Siswa kurang aktif atau kurang komunikatif dalam merespons penjelasan dari guru. Masih banyak siswa yang belum mencapai Kriteria Ketuntasan Minimal 
(KKM). Selama proses pembelajaran berlangsung, guru merupakan poin penting dan utama dalam proses pembelajaran. Mochtar (2017) menyatakan bahwa keberhasilan guru memungkinkannya untuk memutuskan untuk melakukan tugas mengajar menulis kepada siswa karena yakin akan kemampuannya. Guru memberikan petunjuk kepada siswa untuk memfasilitasi selama proses pembelajaran. Untuk menghasilkan sebuah tulisan yang baik, benar, dan bermakna tentu harus mengetahui kaidah penulisan bahasa yang benar. Kenyataannya, masih banyak guru yang kurang memerhatikan mengenai materi kaidah kebahasaan. Hal tersebut sejalan dengan pendapat Sumarwati dkk. (2014) yang menyatakan bahwa pada pembelajaran menulis kaidah kebahasaan tidak rinci dibahas. Kemudian, pembahasaan kaidah kebahasaan hanya fokus pada pelafalan kata saja, dan pada keterampilan membaca dan mendengarkan pembahasaan kaidah kebahasaan hanya fokus pada kata-kata baru atau kata-kata sulit.

Puspitaningrum (2019) menyatakan bahwa keterampilan menulis adalah keterampilan menyampaikan pesan penulis kepada pembaca, sehingga pembaca dapat memahami maksud yang ingin disampaikan oleh penulis kepada pembaca melalui tulisan tersebut. Namun, fakta di lapangan atau di kelas masih banyak siswa yang kesulitan dalam menuangkan gagasan atau pikiran ke dalam bentuk tulisan. Hal tersebut sejalan dengan pendapat Bahri (2016) yang menyatakan bahwa rendahnya kemampuan siswa dalam menulis disebabkan oleh dua faktor, yaitu faktor siswa dan faktor strategi pembelajaran. Faktor yang berasal dari siswa, antara lain: motivasi siswa dalam menulis sangat minim atau rendah, kemampuan siswa menafsirkan fakta untuk menjadi sebuah teks masih rendah, serta kemampuan siswa dalam menuangkan gagasan atau pikiran ke dalam bentuk kalimat-kalimat yang mempunyai kesatuan yang logis dan utuh masih rendah.

Faktor-faktor rendahnya kemampuan siswa dalam keterampilan menulis didukung dengan pendapat Budiani (2018), yaitu hasil survei tiga tahun dari Programme for International Student Assessment (PISA) yang dikeluarkan oleh Organisation for Economic Cooperation and Development (OECD) menjelaskan bahwa Kompetensi anak Indonesia dalam hal menulis masih rendah dan tertinggal dengan negara-negara lainnya. Indonesia menduduki peringkat 60 dari 72 negara yang disurvei.

Komponen-komponen pembelajaran yang mendukung satu sama lain dapat membuat pembelajaran menjadi lebih efektif dan komunikatif. Salah satu komponen pembelajaran yang berpengaruh dalam proses pembelajaran adalah strategi pembelajaran yang digunakan oleh guru. Ulusoy dan Dedeoglu (2011) dalam penelitiannya menjelaskan bahwa guru tidak menerapkan strategi membaca dan menulis khusus. Pembelajaran yang efektif dan berkualitas tentu menerapkan strategi yang baik. Pemilihan strategi yang tepat tentu akan meningkatkan kualitas proses pembelajaran. Sebaliknya, apabila guru salah dalam memilih strategi pembelajaran, tentu proses pembelajaran tidak akan berjalan dengan baik dan terkesan monoton. Fakta di kelas masih banyak guru yang belum menggunakan strategi yang sesuai. Beberapa guru masih menggunakan strategi ceramah, yaitu guru hanya menerangkan dan menyampaikan materi kepada siswa dan pembelajaran cenderung berfokus pada guru, sedangkan siswa hanya mendengarkan apa yang disampaikan oleh guru, sehimgga pembelajaran kurang efektif. Hal tersebut sejalan dengan pendapat Bahri (2016) rendahnya kemampuan siswa dalam menulis disebabkan oleh dua faktor, 
yaitu faktor siswa dan faktor strategi pembelajaran. Faktor yang berasal dari luar siswa adalah metode atau strategi pembelajaran menulis belum efektif, serta kurangnya hubungan komunikatif antara guru dan siswa.

Guru memiliki cara atau strategi yang berbeda-beda dalam mengajarkan keterampilan menulis kepada siswa. Hal tersebut sesuai dengan pendapat Thomson (2013) yang menyatakan setiap guru memiliki strategi dan cara yang berbedabeda untuk mengajarkan keterampilan menulis, terutama menulis kreatif. Seseorang yang rajin menulis, keterampilan menulisnya akan semakin baik, jumlah kosakata yang dimilikinya pun tidak sedikit. Hal tersebut membuat seseorang mudah untuk meningkatkan keterampilan menulis.

Pemilahan strategi yang sesuai tentu akan meningkatkan keterampilan menulis siswa, namun jika strategi yang digunakan tersebut tidak sesuai tentu pembelajaran tidak akan berlangsung secara efektif. Terdapat beberapa guru yang kurang berinovasi dalam memilih strategi untuk diterapkan selama proses pembelajaran. Guru kurang berinovasi dalam memilih strategi yang sesuai, siswa juga mengalami kesulitan dalam pembelajaran bahasa, yaitu keterampilan menulis teks eksposisi. Kesulitan tersebut terjadi karena pembelajaran menulis teks eksposisi disampaikan secara konvensional, pemilihan strategi yang kurang sesuai. Hal tersebut menjadikan siswa merasa malas dan bosan mengikuti pembelajaran menulis teks eksposisi. Kondisi seperti ini menyebabkan hasil belajar menulis teks eksposisi siswa menjadi sangat rendah. Rendahnya hasil belajar siswa mencerminkan bahwa tujuan pembelajaran belum dapat dicapai secara optimal. Oleh karena itu, dibutuhkan suatu strategi pembelajaran yang dapat membantu meningkatkan minat dan hasil belajar siswa, khususnya dalam pembelajaran menulis teks eksposisi.

Berdasarkan masalah-masalah tersebut, suatu pembelajaran memerlukan solusi yang baik agar pembelajaran berlangsung secara efektif. Untuk meningkatakan pembelajaran menulis, diperlukan pemilihan strategi yang sesuai. Strategi pembuatan tanggapan terhadap teks adalah strategi yang memungkinkan siswa membaca untuk pemahaman dan kemudian memudahkan siswa memeroleh ide dan gagasan (Crawford et al., 2005, p. 131). Kegiatan membaca pada strategi ini dimaksudkan untuk memeroleh berbagai informasi yang nantinya digunakan sebagai pancingan dalam proses menulis. Keterampilan menulis adalah keterampilan yang tidak dapat dipisahkan dengan keterampilan yang lainnya, salah satunya keterampilan membaca. Semakin banyak pemahaman atau informasi yang dimiliki tentu untuk semakin mudah pulan untuk menentukan sebuah topik sebuah tulisan. Adanya proses membaca dalam strategi ini siswa lebih mudah mendapatkan ide atau gagasan yang nantinya dikembangkan menjadi sebuah tulisan yang utuh sesuai dengan struktur dan kaidah kebahasaan teks yang benar. Langkah-langkah strategi pembuatan tanggapan terhadap teks. Pertama, siswa membaca teks sesuai dengan topik yan ditentukan oleh guru. Kedua,siswa membuat sebuah buku harian. Siswa membuat 2 kolom pada kertas yang diberikan guru. Ketiga, yaitu siswa membuat garis vertikal di tengah selembar kertas kosong. Di sisi kiri, mereka menulis informasi-informasi yang didapatkan setelah membaca teks pada kolom sebelah kiri. Di sisi kanan, mereka menulis tanggapan tentang entri di sisi kiri. Setelah siswa membaca dan mencatat, kemudian membagikan beberapa ide-ide atau tanggapan tersebut. Keempat, siswa 
menulis informasi dan tanggapan tersebut dalam sebuah teks yang utuh.

Strategi komentar terhadap bacaan merupakan strategi yang hampir sama dengan strategi pembuatan tanggapan terhadap teks, namun keduanya memiliki perbedaan. Perbedaan utama adalah strategi pembuatan tanggapan terhadap teks, siswa merefleksikan informasi baru yang diperoleh dari membaca, mendengarkan, atau mengalami dalam buku harian. Pada strategi komentar terhadap bacaan siswa mencerminkan pada proses pembelajaran itu sendiri. Guru dapat meningkatkan kesadaran siswa tentang proses pembelajaran dengan menggunakan strategi komentar terhadap bacaan. Siswa menetapkan tujuan, mencatat tentang waktu belajar mereka, menggambarkan masalah yang mereka alami, dan mencatat keberhasilan.

Langkah-langkah pembelajaran kelompok eksperimen 2 menggunakan strategi komentar terhadap bacaan, yaitu siswa membaca bacaan yang diberikan guru, kemudian siswa menuliskan informasi apa yang telah dipelajari satu minggu selama mengikuti pembelajaran, lalu siswa memberikan komentar terhadap apa yang telah dipelajari, selanjutnya siswa mengembangkan informasi dan komentar yang telah ditulis dalam sebuah paragraf, dan terakhir siswa menulis teks secara utuh sesuai dengan informasi (Crawford et al., 2005, pp. 132-133). Strategi komentar terhadap bacaan menumbuhkan lingkungan belajar dan mengajar siswa dan guru dapat mengalami tingkat kesetaraan dan keterlibatan yang lebih besar. Pada akhir setiap periode kelas, guru menyisahkan waktu sekitar 5 hingga 10 menit dan meminta siswa untuk menulis pada komentar Babcock (2007).

Strategi pembuatan tanggapan terhadap teks dan strategi komentar terhadap bacaan diharapkan mampu untuk meningkatkan hasil belajar siswa, khusunya dalam pembelajaran menulis teks eksposisi. Strategi pembuatan tanggapan terhadap teks adalah strategi yang memungkinkan siswa membaca untuk pemahaman dan kemudian untuk berinteraksi dengan ide-ide yang mereka hadapi. Strategi ini dilakukan dengan cara siswa membuat sebuah buku harian. Namun, buku harian yang dibuat berbeda dengan buku harian pada umumnya. Buku harian tersebut berupa dua kolom atau dua sisi. Kolom sebelah kiri pamahaan siswa setelah membaca sebuah teks. Kemudian pada kolom sebelahnya atau kolom sebelah kanan berisi mengenai refleksi terhadap apa yang telah dibacanya tadi. Strategi komentar terhadap bacaan merupakan strategi catatan pembelajaran dibuat untuk membantu siswa merekam, menyusun, memikirkan, merenungkan, merencanakan, mengembangkan, dan membuktikan pembelajaran yang telah dipelajari oleh siswa.

Permasalahan atau faktor rendahnya keterampilan menulis siswa adalah sulitnya menafsirkan fakta untuk menjadi sebuah teks masih rendah serta kemampuan siswa dalam menuangkan gagasan atau pikiran ke dalam bentuk tulisan. Penggunaan strategi pembuatan tanggapan terhadap teks dan strategi komentar terhadap bacaan dapat meningkatkan keterampilan menulis teks eksposisi karena kedua strategi ini membantu siswa dalam menemukan informasi yang diperoleh, kemudian informasi tersebut dikembangkan dalam sebuah tulisan. Penggunaan kedua strategi tersebut memudahkan siswa dalam menuangkan gagasan dan ide dalam bentuk tulisan. Selain itu, siswa lebih tertarik untuk mengikuti proses pembelajaran menulis teks eksposisi.

\section{METODE}

Jenis penelitian ini merupakan penelitian eksperimen (experimental design) dengan menggunakan true-experimental 
tipe pretest and posttest random assignment control-group design. Penelitian eksperimen ini menggunakan pendekatan kuantitatif, yaitu pendekatan yang memberikan informasi atau data dalam bentuk angka atau kuantitatif. Analisis kuantitatif berdasarkan angka dengan menggunakan analisis statistik (Creswell, 2016, p. 232). Jumlah sampel dalam penelitian ini adaah 92 siswa. Teknik pengambilan sampel yang digunakan dalam penelitian ini adalah teknik cluster random sampling. Cara menentukan sampel penelitian dalam penelitian ini, yaitu dengan mengundi seluruh kelas yang menjadi populasi dalam penelitian ini. Setelah melakukan pengundian sampel, kemudian sampel tersebut diundi lagi untuk menentukan yang menjadi kelompok eksperimen 1, eksperimen 2, dan kelompok kontrol. Kelompok eksperimen 1 menggunakan strategi pembuatan tanggapan terhadap teks, kelompok eksperimen 2 menggunakan strategi komentar terhadap bacaan dan kelompok kontrol menggunakan strategi konvensional.

Instrumen yang digunakan dalam penelitian ini berupa tes. Tes yang dilakukan meliputi kemampuan menulis teks eksposisi. Teknik pengumpulan data dalam penelitian ini melalui tes. Tes tersebut untuk mengukur kemampuan siswa menulis teks eksposisi. Tes dilakukan sebanyak dua kali, yaitu sebelum perlakuan (pretest) dan sesudah perlakuan (posttest). Teknik analisis data yang digunakan dalam penelitian ini, yautu menggunakan analisis varians (anava) satu jalur dengan bantuan progran SPSS versi 22. Analisis tersebut digunakan untuk menguji perbedaan strategi pembuatan tanggapan terhadap teks, strategi komentar terhadap bacaan, dan strategi konvensional yang diterapkan dalam proses pembelajaran menulis teks eksposisi

\section{HASIL PENELITIAN DAN PEMBAHASAN}

Hasil penelitian terdiri dari hasil pretest dan posttest pembelajaran menulis teks eksposisi pada kelompok eksperimen 1, eksperimen 2, dan kelompok kontrol. Perbandingan data nilai pretest dan posttest kelompok eksperimen 1, eksperimen 2, dan kelompok kontrol dalam pembelajaran menulis teks eksposisi berupa jumlah subjek, nilai tertinggi (maksimum), nilai terendah (minimum), nilai rata-rata, nilai tengah (median), nilai yang sering muncul (mode) dan simpangan baku (Std. Deviation). Hasil nilai pretest dan posttest kelompok eksperimen 1, eksperimen 2, dan kelompok kontrol dalam pembelajaran menulis teks eksposisi dapat dilihat pada Tabel 1.

Tabel 1 menunjukkan nilai tes awal (pretest) dan tes akhir (posttest) kelompok eksperimen 1, eksperimen 2, dan kontrol pada pembelajaran menulis teks eksposisi mengalami peningkatan. Rata-rata nilai pretest dan posttest kelompok eksperimen 1 mengalami peningkatan. Niai ratarata pretest kelompok eksperimen 1 sebesar 75,03 dan nilai posttest kelompok eksperimen 1 sebesar 86,23. Kelompok eksperimen 2 juga mengalami peningkatan; yaitu nilai pretest sebesar 75,80 dan nilai posttest kelompok eksperimen 2 sebesar 83,37 . Kelompok kontrol juga mengalami peningkatan; yaitu nilai pretest kelompok kontrol sebesar 75,50 dan nilai posttest kelompok kontrol sebesar 80,50. Kelompok eksperimen 1 mengalami peningkatan sebesar 11,2. Kelompok eksperimen 2 mengalami peningkatan sebesar 7,57. Kelompok kontrol mengalami peningkatan sebesar 5,0.

Analisis data dalam penelitian ini menggunakan uji anava. Uji anava Scheffe data posttest pembelajaran menulis teks eksposisi kelompok eksperimen 1, eksperimen 2, dan kontrol bertujuan 
Tabel 1

Hasil Nilai Pretest dan Posttest

\begin{tabular}{lcccccc}
\hline \multirow{2}{*}{\multicolumn{1}{c}{ Data }} & \multicolumn{2}{c}{$\begin{array}{c}\text { Kelompok } \\
\text { Eksperimen 1 }\end{array}$} & \multicolumn{2}{c}{$\begin{array}{c}\text { Kelompok } \\
\text { Eksperimen 2 }\end{array}$} & \multicolumn{2}{c}{$\begin{array}{c}\text { Kelompok } \\
\text { Kontrol }\end{array}$} \\
\cline { 2 - 7 } & Pretest & Posttest & Pretest & Posttest & Pretest & Posttest \\
\hline Jumlah subjek & 30 & 30 & 30 & 30 & 32 & 32 \\
Nilai tertinggi (Maksimum) & 85 & 96 & 88 & 97 & 85 & 91 \\
Nilai terendah (Minimum) & 59 & 78 & 58 & 75 & 60 & 74 \\
Nilai rata-rata (Mean) & 75,03 & 86,23 & 75,80 & 83,37 & 75,50 & 80,75 \\
Nilai Tengah (Median) & 76,00 & 86,00 & 75,50 & 83,00 & 75,50 & 80,50 \\
Nilai yang sering muncul & 76 & 85 & 75 & 82 & 72 & 76 \\
(Mode) & & & & & & \\
Simpangan Baku (Std. Deviasi) & 6,531 & 4,659 & 6,488 & 5,055 & 5,787 & 4,212 \\
\hline
\end{tabular}

untuk menguji dan mengetahui perbedaan strategi yang digunakan. Selain itu, untuk mengetahui stretegi yang paling efektif digunakan dalam pembelajaran menulis teks eksposisi. Hasil uji anava scheffe posttest kelompok eksperimen 1, eksperimen 2, dan kontrol dapat dilihat pada Tabel 2.

Tabel 2 menunjukkan hasil uji anava scheffe posttest pembelajaran menulis teks eksposisi kelompok eksperimen 1, eksperimen 2, dan kontrol. Tabel 2 menunjukkan hasil uji anava scheffe posttest kelompok eksperimen 1 dan eksperimen 2 diperoleh nilai mean difference sebesar 2,800 dengan taraf singnifikansi atau $P$ sebesar 0,068 . Nilai $P>0,05$ artinya strategi pembuatan tanggapan dan strategi komentar terhadap bacaan tidak ada perbedaan yang signifikan atau kedua strategi tersebut baik digunakan dalam pembelajaran menulis teks eksposisi.

Hasil uji anava scheffe posttest kelompok eksperimen 1 dan kelompok kontrol diperoleh nilai mean difference sebesar 5,733 dengan taraf signifikansi atau $P$ sebesar 0,000 . Nilai $P<0,05$. Hasil uji anava scheffe posttest kelompok eksperimen 1 dan kelompok kontrol menunjukkan bahwa strategi pembuatan tanggapan terhadap teks yang diterapkan pada kelompok eksperimen 1 lebih efektif dibandingan dengan strategi konvensional. Hasil uji anava scheffe posttest kelompok eksperimen 2 dan eksperimen 1 diperoleh

Tabel 2

Hasil Uji Anava Scheffe Data Posttest Kelompok Eksperimen 1, Eksperimen 2, dan Kontrol

\begin{tabular}{|c|c|c|c|c|c|c|}
\hline \multirow{2}{*}{\multicolumn{2}{|c|}{ Kelompok }} & \multirow{2}{*}{$\begin{array}{c}\text { Mean } \\
\text { Difference }\end{array}$} & \multirow{2}{*}{$\begin{array}{c}\text { Std. } \\
\text { Error }\end{array}$} & \multirow{2}{*}{ Sig. } & \multicolumn{2}{|c|}{ 95\% Confidence Internal } \\
\hline & & & & & Lower Bound & Upper Bound \\
\hline \multirow[t]{2}{*}{ Eksperimen 1} & Eksperimen 2 & 2,80000 & 1,18945 & ,068 &,- 1612 & 5,7612 \\
\hline & Kontrol & $5,73333 *$ & 1,17071 &, 000 & 2,8188 & 8,6479 \\
\hline \multirow[t]{2}{*}{ Eksperimen 2} & Eksperimen 1 & $-2,80000$ & 1,18945 &, 068 & $-5,7612$ &, 1612 \\
\hline & Kontrol & $2,93333 *$ & 1,17071 &, 048 &, 0188 & 5,8479 \\
\hline \multirow[t]{2}{*}{ Kontrol } & Eksperimen 1 & $-5,73333 *$ & 1,17071 &, 000 & $-8,6479$ & $-2,8188$ \\
\hline & Eksperimen 2 & $-2,93333^{*}$ & 1,17071 &, 048 & $-5,8479$ &,- 0188 \\
\hline
\end{tabular}


nilai mean difference sebesar -2,800 dengan taraf signifikansi atau $P$ sebesar 0,068 . Nilai $P>0,05$. Hasil tersebut menunjukkan bahwa strategi pembuatan tanggapan dan strategi komentar terhadap bacaan tidak ada perbedaan yang signifikan. Kedua strategi tersebut baik digunakan dalam pembelajaran menulis teks eksposisi.

Hasil uji anava scheffe posttest kelompok eksperimen 2 dan kelompok kontrol diperoleh nilai mean difference sebesar 2,933 dengan taraf signifikansi atau $P$ sebesar 0,048 . Nilai $P<0,05$. Hasil uji anava scheffe posttest kelompok eksperimen 2 dan kontrol menunjukkan bahwa strategi komentar terhadap bacaan yang diterapkan pada kelompok eksperimen 2 lebih efektif dibandingan dengan strategi konvensional.

Hasil uji anava scheffe posttest kelompok kontrol dan kelompok eksperimen 1 diperoleh nilai mean difference sebesar $-5,733$ dengan taraf signifikansi atau $P$ sebesar 0,000 . Nilai $P<0,05$. Hasil uji anava scheffe posttest kelompok kontrol dan kelompok eksperimen 1 menunjukkan bahwa strategi konvesional lebih efektif dibandingan dengan strategi Pembuatan Tanggapan terhadap Teks. Hasil uji anava scheffe posttest kelompok kontrol dan eksperimen 2 diperoleh nilai mean difference sebesar -2,933 dengan taraf signifikansi atau $P$ sebesar 0,048 . Nilai $P<0,05$. Hasil uji anava scheffe posttest kelompok eksperimen 2 dan kelompok kontrol menunjukkan bahwa konvensional lebih efektif dibandingkan dengan strategi komentar terhadap bacaan. Tingkat keefektifan strategi yang digunakan pada kelompok eksperimen 1, eksperimen 2, dan kelompok kontrol apabila diurutkan berdasarkan nilai signifikansi uji anava scheffe dari yang paling kecil atau $P<0,05$; yaitu strategi pembuatan tanggapan terhadap teks, strategi komentar terhadap bacaan, dan strategi konvensional.
Pengujian hipotesis dilakukan dengan mengubah $\mathrm{H}_{\mathrm{a}}$ menjadi $\mathrm{H}_{\mathrm{o}}$, yaitu "Tidak ada perbedaan keterampilan menulis teks eksposisi antara siswa yang mengikuti pembelajaran menggunakan strategi pembuatan tanggapan terhadap teks dengan siswa yang mengikuti pembelajaran menulis teks eksposisi menggunakan strategi konvensional". Uji hipotesis pertama pada penelitian ini dilakukan dengan cara mencari perbedaan nilai posttest keterampilan menulis teks eksposisi kelompok eksperimen 1 dan kontrol. Berdasarkan hasil uji anava scheffe data posttest kelompok eksperimen 1 dan kontrol diperoleh nilai mean difference sebesar -0,433 dengan taraf singnifikansi 0,00 . Berdasarkan hasil uji anava scheffe tersebut, nilai $P<0,05$. Artinya, data nilai posttest kelompok eksperimen 1 dan kontrol singnifikan.

Pengujian hipotesis dilakukan dengan mengubah $\mathrm{H}_{\mathrm{a}}$ menjadi $\mathrm{H}_{\mathrm{o}}$, yaitu "Tidak ada perbedaan yang singnifikan keterampilan menulis teks eksposisi antara siswa yang mengikuti pembelajaran menggunakan strategi komentar terhadap bacaan dengan siswa yang mengikuti pembelajaran menulis teks eksposisi menggunakan strategi konvensional". Uji hipotesis kedua pada penelitian ini dilakukan dengan cara mencari perbedaan nilai posttest keterampilan menulis teks eksposisi kelompok eksperimen 2 dan kontrol. Berdasarkan hasil hasil uji anava scheffe data posttest kelompok eksperimen 2 dan kontrol diperoleh nilai mean difference sebesar 2,933 dengan Sig. 0,048 . Berdasarkan hasil uji anava scheffe tersebut, nilai $P<0,05$ yang artinya data nilai posttest kelompok eksperimen 2 dan kontrol signifikan.

Pengujian hipotesis dilakukan dengan mengubah $\mathrm{H}_{\mathrm{a}}$ menjadi $\mathrm{H}_{\mathrm{o}}$, yaitu "Pembelajaran keterampilan menulis teks 
eksposisi menggunakan strategi pembuatan tanggapan terhadap teks tidak lebih efektif dibandingkan dengan menggunakan strategi komentar terhadap bacaan". Uji hipotesis ketiga pada penelitian ini dilakukan dengan cara mencari perbedaan nilai posttest keterampilan menulis teks eksposisi kelompok eksperimen 1 dan eksperimen 2. Berdasarkan hasil hasil uji anava scheffe data posttest kelompok eksperimen 1 memeroleh nilai mean difference sebesar 2,800 dengan taraf signifikansi 0,068 atau nilai $P>0,05$, sedangkan kelompok eksperimen 2 memeroleh nilai mean difference sebesar $-2,800$ dengan taraf signifikansi 0,068 atau nilai $P>0,05$. Berdasarkan hasil uji anava scheffe, kedua strategi tersebut samasama baik digunakan dalam pembelajaran menulis teks eksposisi. Namun, untuk membandingkan strategi yang lebih spesifik, kelompok yang memeroleh hasil mean defference positif lebih unggul daripada kelompok yang memeroleh hasil mean defference negatif.

Pada kelompok kontrol tidak menggunakan strategi khusus, guru hanya menerangkan materi dan meminta siswa untuk menulis teks eksposisi. Pembelajaran kelompok kontrol terlihat monoton, beberapa siswa tidak terlalu aktif dalam mengikuti proses pembelajaran. Berbeda dengan kelompok kontrol, kelompok eksperimen 1 mendapatkan perlakuan menggunakan strategi pembuatan tanggapan terhadap teks. Kelompok eksperimen 1 mendapat 4 kali perlakuan. Perlakuan pertama, siswa membaca teks eksposisi yang diberikan guru, yaitu berjudul "Mencegah Kebiasaan Buruk" dan "Mencegah Kecanduan Gawai (Gadget) pada Anak". Perlakuan kedua, kelompok eksperimen 1 siswa membaca teks eksposisi dengan judul yang berbeda dengan pertemuan pertama, yaitu "Sampah Rumah Tangga" dan
"Pemanasan Global dan Hilangnya Hutan Lindung". Di perlakuan kedua, siswa lebih mudah dan cepat dalam menuliskan informasi-informasi yang diperoleh dari teks. Perlakuan ketiga, siswa kembali membaca teks eksposisi yang berjudul "Pentingnya Menjaga Kelestarian Hutan" dan "Menjaga Kebersihan Lingkungan". Perlakuan keempat, judul teks yang diberikan adalah "Pendidikan Karakter" dan "Nasib Hutan Kita Semakin Suram". Setelah siswa membaca dengan saksama teks tersebut, kemudian siswa menuliskan informasi pada catatan yang telah dibuat sebelumnya. Informasi-informasi dari teks ditulis pada kolom sebelah kiri. Kolom sebelah kanan siswa menuliskan tanggapan terhadap informasi yang dituliskan pada kolom sebelah kiri. Informasi-informasi yang dituliskan pada kolom sebelah kiri tersebut dijadikan sebagai ide-ide untuk menulis teks eksposisi, sedangkan tanggapan yang ditulis pada kolom sebelah kanan dijadikan untuk memperkuat ideide dalam teks eksposisi. Beberapa siswa tampak kebingungan menuliskan informasi yang diperoleh karena dalam menuliskan informasi tersebut tidak diperkenankan melihat teks. Siswa harus membaca dan memahami dengan benar teks tersebut untuk menulis informasi yang diperoleh. Hal tersebut sesuai dengan teori Crawford et al. (2005, p. 131), strategi pembuatan tanggapan terhadap Teks adalah strategi yang memungkinkan siswa membaca untuk pemahaman dan memeroleh informasi dan ide gagasan yang diperoleh dari teks yang dibaca.

Kelompok eksperimen 2 mendapat 4 kali perlakuan. Pada perlakuan pertama, siswa membaca buku bacaan mata pelajaran Ilmu Pengetahuan Alam. Siswa tidak hanya membaca buku paket Ilmu Pengetahuan Alam saja, tetapi siswa juga membaca buku catatan pelajaran yang sudah ditulis 
selama mengikuti pembelajaran tersebut. Siswa tentu menulis catatan yang dijelaskan oleh guru mata pelajaran. Setelah siswa membaca buku bacaan tersebut, kemudian siswa memilih satu topik yang terdapat pada buku bacaan tersebut. Setelah memilih topik, siswa menuliskan komentar terhadap topik yang sudah ditulis tersebut. Siswa menulis topik atau hal-hal yang sudah dipelajari. Kemudian, siswa menuliskan komentar terhadap topik yang ditulis tersebut, seperti hal-hal yang sudah dipahami atau dimengerti dan mengatasi masalah atau kendala yang dihadapi. Catatan-catatan tersebut digunakan sebagai bahan untuk menulis teks eksposisi. Pada perlakuan pertama ini, beberapa siswa ada yang kebingungan karena banyak materi. Tetapi, guru kemudian menjelaskan bahwa hanya materi yang dipelajari selama satu minggu untuk ditulis sebagai catatan untuk menulis teks eksposisi. Dalam hal ini, selain buku paket mata pelajaran, buku catatan pembelajaran juga sangat penting untuk menuliskan hal-hal yang sudah dipelajari dan didapatkan selama satu minggu mengikuti pembelajaran tersebut.

Perlakuan kedua sampai dengan perlakuan keempat sama seperti pada perlakuan pertama hanya saja berbeda pada buku bacaan yang digunakan. Pada perlakuan kedua buku bacaan yang digunakan adalah buku Olahraga. Pada perlakuan ketiga buku bacaan yang digunakan adalah buku mata pelajaran Ilmu Pengetahuan Sosial dan perlakuan terakhir, yaitu perlakuan keempat buku bacaan yang digunakan adalah buku mata pelajaran PKN. Setelah keempat perlakuan diberikan kelompok eksperimen 2, kemudian pada pertemuan selanjutnya siswa menulis teks eksposisi. Siswa memilih topik dari beberapa catatan yang sudah ditulis pada pertemuan-pertemuan sebelumnya. Setelah memilih topik dari catatan tersebut, siswa menulis teks eksposisi berdasarkan topik yang dipilih. Siswa menulis sesuai dengan struktur teks eksposisi yang benar. Siswa kelompok eksperimen 2 lebih mudah untuk menuliskan dan mengembangkan gagasangagasan ke dalam teks eksposisi karena memiliki catatan yang sudah ditulis dari keempat perlakuan. Dibandingkan dengan kelompok kontrol, hasil teks eksposisi kelompok eksperimen 1 lebih baik dari segi tulisan, ejaan, dan penggunaan bahasanya.

Kelompok eksperimen 1 dan 2 samasama mendapat perlakuan menggunakan strategi dalam proses pembelajaran. Kelompok eksperimen 1 mendapat perlakuan dengan strategi pembuatan tanggapan terhadap teks. Kelompok eksperimen 2 mendapat perlakuan meng-gunakan strategi komentar terhadap bacaan. Kedua strategi tersebut sekilas memang hampir sama, yaitu keduanya strategi tersebut berupa tanggapan dan komentar, tetapi kedua strategi tersebut memiliki perbedaan. Strategi pembuatan tanggapan terhadap teks adalah strategi yang memberikan tanggapan sesuai dengan teks yang diberikan oleh guru dan menulis informasi dalam sebuah buku harian yang dibuat menjadi 2 kolom, sedangkan strategi komentar terhadap bacaan adalah strategi yang memberikan komentar terhadap bacaan-bacaan yang telah dipelajari selama satu minggu mengikuti pembelajaran.

Kedua strategi yang digunakan dalam penelitian ini hampir sama, tapi berbeda pada langkah-langkahnya. Langkahlangkah strategi pembuatan tanggapan terhadap teks. Pertama, siswa membaca teks sesuai dengan topik yan ditentukan oleh guru. Kedua, siswa membuat sebuah buku harian. Siswa membuat 2 kolom pada kertas yang diberikan guru dengan membuat garis vertikal di tengah selembar kertas kosong. Di sisi kiri, mereka menulis informasi-informasi yang didapatkan setelah membaca teks pada kolom sebelah 
kiri. Pada sisi kanan, siswa menulis tanggapan tentang informasi di sisi kiri, kemudian siswa membaca dan mencatat, kemudian membagikan beberapa ide-ide atau tanggapan tersebut. Ketiga, siswa menulis informasi dan tanggapan tersebut dalam sebuah teks yang utuh.

Langkah-langkah strategi komentar terhadap bacaan. Pertama, siswa membaca bacaan yang diberikan guru. Kedua, siswa menuliskan informasi yang telah dipelajari satu minggu selama mengikuti pembelajaran. Ketiga, siswa memberikan komentar terhadap yang telah dipelajari. Keempat, siswa mengembangkan informasi dan komentar yang telah ditulis dalam sebuah paragraf. Kelima, siswa menulis teks secara utuh sesuai dengan informasi (Crawford et al., 2005, pp. 131-133).

Siswa kelompok eksperimen 1 lebih mudah untuk menulis teks eksposisi dengan adanya informasi dan tanggapan yang sudah ditulis. Siswa lebih mudah untuk mengembangkan ide dan gagasannya. Berbeda dengan kelompok eksperimen 1, kelompok eksperimen 2 siswa tidak diberi teks. Siswa diminta untuk membaca buku bacaan, yaitu buku mata pelajaran dan buku catatan pelajaran. Setiap pertemuan atau satu kali perlakuan, guru meminta siswa untuk membaca dan memahami materi yang telah dipelajari selama satu minggu. Pada perlakuan pertama, guru meminta siswa untuk membaca dan memahami buku bacaan mata pelajaran Ilmu Pengetahuan Alam. Pada perlakuan kedua, buku bacaan yang digunakan adalah buku pelajaran Olahraga. Pada perlakuan ketiga, buku bacaan yang digunakan adalah buku mata pelajaran Ilmu Pengetahuan Sosial. Pada perlakuan keempat, buku bacaan yang digunakan adalah buku mata pelajaran PKn. Buku-buku bacaan yang digunakan pada perlakuan kelompok eksperimen 2 sudah disepakati antara guru dan murid dan disesuaikan dengan jadwal pelajaran.

Kelompok eksperimen 2 memiliki banyak bacaan yang berasal dari beberapa buku mata pelajaran dan buku catatan siswa. Strategi komentar terhadap bacaan ini baik karena siswa dapat menggali informasi sebanyak mungkin dari beberapa buku yang dibaca tersebut. Tetapi, dari banyaknya informasi tersebut beberapa siswa merasa bingung karena tidak semua materi atau informasi disampaikan oleh guru selama satu minggu pembelajaran. Selain itu, tidak semua siswa mencatat informasi yang dijelaskan oleh guru mata pelajaran dan ditulis di buku catatan sehingga informasi yang diperoleh hanya terbatas. Siswa tidak terfokus pada satu atau dua topik yang jelas.

Dibandingkan dengan kelompok eksperimen 2, kelompok eksperimen 1 yang menggunakan strategi pembuatan tanggapan terhadap teks lebih terarah dan terstruktur. Beberapa topik teks yang diberikan guru tidak terlalau banyak sehingga tidak membuat siswa bingung untuk menentukan topik yang bagus untuk menulis teks eksposisi. Siswa kelompok eksperimen 1 juga lebih mudah dalam mengembangkan ide dan gagasan dalam bentuk teks eksposisi.

Dilihat dari hasil akhir menulis teks eksposisi kedua kelompok juga baik. Hasil menulis teks eksposisi pada kelompok eksperimen 2 sudah baik, tetapi masih ada beberapa kesalahan dari segi isi teks, pemilihan kosakata, penggunaan bahasa, dan ejaan. Sementara itu, hasil menulis teks eksposisi kelompok eksperimen 1 lebih baik jika dibandingkan dengan kelompok eksperimen 2. Walaupun masih ada beberapa kesalahan dari segi isi teks, pemilihan kosakata, penggunaan bahasa, dan ejaan, tetapi tidak sebanyak kesalahan kelompok eksperimen 2 .

Berdasarkan hasil pretest dan posttest kelompok eksperimen 1 dan kelompok 
eksperimen 2 juga terdapat perbedaan. Hasil pretest kelompok eksperimen 1 diperoleh sebesar 75,03 dan hasil posttest kelompok eksperimen 1 sebesar 86,23. Hasil pretest kelompok eksperimen 2 diperoleh sebesar 75,80 dan hasil posttest kelompok eksperimen 2 sebesar 83,37. Berdasarkan hasil pretest dan posttest tersebut, kelompok eksperimen 1 mengalami kenaikan sebesar 11,2; sedangkan kelompok eksperimen 2 mengalami kenaikan sebesar 7,57.

Hasil hasil uji anava scheffe data posttest kelompok eksperimen 1 memeroleh nilai mean difference sebesar 2,800 dengan taraf signifikansi 0,068 atau nilai $P>0,05$; sedangkan kelompok eksperimen 2 memeroleh nilai mean difference sebesar -2,800 dengan taraf signifikansi 0,068 atau nilai $P>0,05$. Berdasarkan hasil uji anava scheffe, kedua strategi tersebut samasama baik digunakan dalam pembelajaran menulis teks eksposisi. Namun, untuk membandingkan strategi yang lebih spesifik, kelompok yang memeroleh hasil mean defference positif lebih unggul daripada kelompok yang memeroleh hasil mean defference negatif. Berdasarkan uraian di atas dapat disimpulkan bahwa pembelajaran menulis teks eksposisi dengan menggunakan strategi pembuatan tanggapan terhadap teks lebih efektif dibandingkan dengan pembelajaran menulis teks eksposisi dengan strategi komentar terhadap bacaan.

\section{SIMPULAN}

Berdasarkan hasil penelitian dan pembahasan, dapat disimpulkan tiga hal. Pertama, terdapat perbedaan yang signifikan antara pembelajaran menulis teks eksposisi menggunakan strategi pembuatan tanggapan terhadap teks dan pembelajaran menulis teks eksposisi menggunakan strategi konvensional. Pembelajaran menulis teks eksposisi kelompok eksperimen 1 dengan menggunakan strategi pembuatan tanggapan terhadap teks dan kelompok kontrol signifikan. Kedua, yaitu terdapat perbedaan yang signifikan antara pembelajaran menulis teks eksposisi menggunakan strategi komentar terhadap bacaan. Pembelajaran menulis teks eksposisi kelompok eksperimen 2 yang menggunakan strategi komentar terhadap bacaan dan kelompok kontrol signifikan. Ketiga, yaitu pembelajaran menulis teks eksposisi menggunakan strategi pembuatan tanggapan terhadap teks lebih efektif dibandingkan dengan pembelajaran menulis menggunakan strategi komentar terhadap bacaan. Kedua strategi tersebut sama-sama baik digunakan dalam pembelajaran menulis teks eksposisi. Namun, untuk membandingkan strategi yang lebih spesifik, kelompok yang memeroleh hasil mean defference positif lebih unggul daripada kelompok yang memeroleh hasil mean defference negatif, jadi strategi pembuatan tanggapan terhadap teks yang diterapkan pada kelompok eksperimen 1 lebih unggul daripada strategi komentar terhadap bacaan yang diterapkan pada kelompok eksperimen 2.

\section{DAFTAR PUSTAKA}

Abidin, Y. (2012). Pembelajaran bahasa berbasis pendidikan karakter. PT Refika Aditama.

Babcock, M. J. (2007). Learning log in introductory literature courses. Teaching in Higher Education, 12(4), 513-523. http://www.tandfonline.com/doi/ full/10.1080/13562510701415615.

Bahri, A. (2016). Peningkatan keterampilan menulis teks eksposisi dengan menggunakan metode cush word. Konfiks Jurnal Bahasa, Sastra, dan Pengajaran, 3(2), 93-102. https:// journal.unismuh.ac.id/index.php/ konfiks/article/view/391. 
Balta, E. E. (2018). The relationships among writing skill, writing anxiety and metacognitive awareness. Journal of Education and Learning, 7(3), 233241. https://files.eric.ed.gov/fulltext/ EJ1174453.pdf.

Basuki, Suryani, Y. E., \& Setiyadi D. B. P. (2017). Kesulitan belajar siswa dalam pembelajaran bahasa Indonesia. Jurnal Litera, 16(1), 12-20. https://journal. uny.ac.id/index.php/litera/article/ view/14247/9434.

Budiani, S. A. (2018). Peningkatan keterampilan menulis teks eksposisi dengan menggunakan metode brainwriting. Pedagogie, 13(1), 37-42. http://www.ccsenet.org/journal/index. $\mathrm{php} / \mathrm{jel} /$ article/view/73463.

Creswell, J. W. (2017). Research design pendekatan metode kualitatif, kuantitatif, dan campuran. Pustaka Pelajar.

Crawford, A., Saul, E. W., Mathews, S., \& Makinster, J. (2005). Teaching and learning strategies for the thinking classroom. The International Debate Education Association.

Durfee, P. B. (2012). Writing to learn in teachical writing. College Teaching, 37(1), 8-11. https://doi.org/10.1080/8 7567555.1989.10532145.

Javed, M., Juan W. X., \& Nazli S. (2013). A study of students assesment in writing skills of the english language. International Journal of Instruction, 6(2) 129-144. https://files.eric.ed.gov/ fulltext/ED544075.pdf.

Kosasih, E. (2017). Buku guru bahasa Indonesia untuk SMP/MTS Kelas VIII. Pusat Kurikulum dan Perbukuan Balitbang Kemendikbud.

Mijianti, Y., \& Puspitosari, E. P. (2019). Peningkatan keterampilan menulis teks eksposisi dengan menggunakan metode take and give dengan pemanfaatan strategi 3W2H. Belajar Bahasa, 4(1), 149-159. http://jurnal. unmuhjember.ac.id/index.php/BB/ article/view/1873/1537.

Mochtar. (2017). Analysis of teacher beliefs and efficacy for teaching writing to weak learners. English Language Teaching, 10(9), 208-217. http://doi. org/10.5539/elt.v10n9p208.

Puspitaningrum, I. (2019). Peningkatan keterampilan menulis teks eksposisi dengan menggunakan metode Inquiry pada siswa kelas VIII SMP Negeri 1 Banyumas. Jurnal Metafora, 5(2), 116-130. http:// jurnalnasional.ump. ac.id/index.php/METAFORA/article/ view/5078/2648.

Sumarwati, Anindyarini, A., \& Fuady, A. (2014). Pembelajaran kaidah bahasa Indonesia dan keterampilan berbahasa secara terpadu dengan pendekatan focus on form pada siswa sekolah menengah pertama. Litera, 13(1), 103113. https://journal.uny.ac.id/index. php/litera/article/view/1906/1560.

Syamsi, K. (2012). Model perangkat pembelajaran menulis berdasarkan pendekatan proses genre bagi siswa smp. Litera, 11(2), 288-297. https:// journal.uny.ac.id/index.php/litera/ article/view/1070/942.

Thomson, L. (2013). Learning to teach creative writing. Changing English, 20(1), 45-52. https://www.tandfonline. $\mathrm{com} / \mathrm{doi} / \mathrm{abs} / 10.1080 / 135868$ 4X.2012.757060.

Ulusoy, M., \& Dedeoglu, H. (2011). Content area reading and writing: Practices and beliefs. Australian Journal of Teacher Education, 36(4), 1-16. https://ro.ecu.edu.au/cgi/viewcontent. cgi? article $=1546 \&$ context $=$ ajte.

Zuchdi, D. (2011). Pendidikan karakter dalam perspektif teori dan praktik. UNY Press. 